\title{
Onomatope yang digunakan oleh Food blogger Jepang dalam Media Sosial Instagram
}

\author{
Ni Putu Ayu Roslia*, Ketut Widya Purnawati, I Nyoman Rauh Artana \\ Program Studi Sastra Jepang Fakultas Ilmu Budaya \\ [ayuroslia1@gmail.com] [tuti@unud.ac.id] \\ [rauhartana@gmail.com] \\ Gianyar, Bali, Indonesia \\ *Corresponding Author
}

\begin{abstract}
The title of this research is "Onomatopoeia Used by Japanese Food blogger on Social Media site Instagram". This research focuses on the form, function and meaning contained in onomatopoeia used by Japanese food bloggers on Social Media site Instagram. The theories used in this study are The Onomatopoeia Theory by Toshiko and Hoshino (1995: vi), Theory of Grammatical Onomatopoeic Functions by Fukuda(2003) and Semantic Theory by Chaer (2009). The results obtained in this study are that of the 25 data discussed there were 21 pieces of onomatopoeia data of the type of gitaigo and 4 pieces of onomatopoeia data of type giongo. Not all the same onomatopoeia always have the same grammatical function. In general, onomatopoeia meaning will change when the position of onomatopoeia as an adverbial in the relative clause in the sentence is to explain the noun that follows it.
\end{abstract}

Keywords: Onomatopoeia, form, function, meaning, food blogger, instagram

\begin{abstract}
Abstrak
Penelitian ini berjudul onomatope yang digunakan oleh food blogger jepang dalam media sosial instagram. Penelitian ini berfokus pada bentuk, fungsi dan makna yang terkandung dalam onomatope yang digunakan oleh food blogger Jepang dalam media sosial instagram. Teori yang digunakan dalam penelitian ini adalah Teori Onomatope menurut Toshiko dan Hoshino (1995:vi), Teori Fungsi Gramatikal Onomatope menurut Fukuda (2003) dan Teori Semantik menurut Chaer (2009). Hasil yang diperoleh dalam penelitian ini adalah bahwa dari 25 data yang dibahas terdapat 21 buah data onomatope yang berjenis gitaigo dan 4 buah data onomatope yang berjenis giongo. Dan tidak semua onomatope yang sama selalu memiliki fungsi gramatikal yang sama. Secara umum onomatope mengalami pergeseran makna ketika posisi onomatope sebagai adverbial dalam klausa relatif dalam kalimat yaitu menerangkan kata benda yang mengikutinya.
\end{abstract}

Kata kunci : onomatope, bentuk, fungsi, makna, food blogger, instagram

\section{Latar Belakang}

Onomatope masih menjadi istilah yang jarang diketahui oleh masyarakat umum, meskipun secara tidak sadar onomatope sering didengar dan digunakan dalam kehidupan sehari-hari. Misalnya onomatope yang digunakan untuk mewakili suara binatang, suara menangis, suara tertawa, dan bahkan ada onomatope yang digunakan untuk 
mengungkapkan perasaan seseorang. Onomatope tidak hanya dalam bahasa Indonesia saja, setiap bahasa di dunia tentu memiliki definisi onomatope yang sama tetapi dalam bentuk yang berbeda dan tentu memiliki ciri khasnya sendiri, salah satunya dalam bahasa Jepang.

Tamori dan Lawrence (1998:10) menyatakan bahwa onomatope dalam bahasa Jepang secara umum merupakan kata-kata yang menirukan dan mengekspresikan suara atau bunyi secara nyata, atau minimal mengacu kepada suara atau bunyi yang mirip dan mendekati suara aslinya, Seperti gishigishi 'mendecit' dan lain-lain. Tetapi istilah ini tidak hanya mengacu kepada kata atau bahasa yang menunjukkan bunyi yang mengandung suara saja, tetapi juga kata-kata yang mendeskripsikan keadaan atau kondisi perbuatan dan pergerakan misalnya, kunekune, 'meliak-liuk'. Untuk menunjukkan kondisi fisik misalnya pocchari 'montok'. Jika diklasifikasikan, kata-kata yang mengungkapkan bunyi atau suara disebut dengan giongo, sedangkan kata yang mengungkapkan keadaan atau kondisi disebut gitaigo. Dari penjelasan tersebut dapat diketahui bahwa onomatope dalam bahasa Jepang lebih beragam karena tidak terbatas pada tiruan bunyi saja. Oleh karena itu onomatope bukanlah hal yang asing bagi orang Jepang mengingat jumlah onomatope dalam bahasa Jepang sangat banyak dan sangat sering digunakan dalam percakapan sehari-hari.

Onomatope tidak hanya ditemukan dalam percakapan sehari-hari, onomatope juga ditemukan pada iklan, koran, bahkan dalam nama produk makanan sering digunakan untuk membuat kesan dari makanan yang dijual atau ditampilkan lebih menarik (Tamori, 2002:49). Onomatope tidak hanyak digunakan pada karya sastra saja, namun dipakai juga dalam media sosial. Dengan pesatnya perkembangan teknologi seperti sekarang, masyarakat pengguna media sosial juga semakin bertambah. Media sosial tersebut antara lain seperti facebook, line, twitter, dan instagram. Beberapa alasan tersebut membuat penelitian ini menjadi menarik untuk dibahas. Penelitian ini juga memakai media sosial instagram sebagai sumber yang sangat populer belakangan ini.

\section{Rumusan Masalah}

Berdasarkan latar belakang yang telah diuraikan di atas, masalah yang dibahas dalam penelitian ini adalah mengenai bentuk, fungsi dan makna onomatope yang terdapat dalam media sosial instagram yang digunakan oleh food blogger Jepang?

\section{Tujuan Penelitian}

Penelitian ini bertujuan untuk menambah wawasan pembelajar bahasa Jepang mengenai linguistik bahasa Jepang. Khususnya dalam memahami bentuk, fungsi dan makna onomatope dalam foto yang diunggah oleh food blogger Jepang dalam media sosial instagram. Secara khusus penelitian ini bertujuan untuk mengetahui bentuk, fungsi dan makna onomatope yang digunakan oleh food blogger Jepang dalam media sosial instagram.

\section{Metode Penelitian}

Metode yang digunakan dalam penelitian ini adalah metode agih dan metode padan translasional. Metode agih adalah metode analisis yang unsur penentunya ada di dalam dan merupakan bagian dari bahasa yang bersangktan itu sendiri. Penelitian ini mengambil salah satu teknik analisis dari metode agih yaitu teknik bagi unsur langsung. Teknik bagi unsur langsung yaitu teknik urai unsur terkecil atau mengurai suatu lingual tertentu atau unsur-unsur terkecilnya (Surdayanto, 1993:15). Sementara metode padan translasional adalah metode dengan alat penentunya 
merupakan bahasa atau lingual lain (Surdayanto, 1993:13). Onomatope dalam caption instagram dipisahkan menggunakan metode agih kemudian dicari artinya menggunakan metode padan translasional, setelah itu onomatope yang sudah diterjemahkan artinya dari bahasa jepang ke dalam bahasa Indonesia dicari bentuk, jenis, dan fungsi gramatikalnya kemudian dilanjutkan dengan menganalisis maknanya.

\section{Hasil dan Pembahasan}

Berikut adalah pembahasan mengenai onomatope yang digunakan oleh food blogger Jepang dalam media sosial instagram. Setiap onomatope mempunyai fungsi gramatikal dan makna yang berbeda-beda. Fungsi gramatikal onomatope mengalami perubahan sesuai dengan kelas kata yang mengikutinya dan makna yang paling banyak muncul yaitu kemunculan makna leksikal sebanyak 7 kali, makna gramatikal sebanyak 5 kali yang dipengaruhi oleh proses gramatikal, makna kontekstual sebanyak 5 kali karena penyesuaian dengan konteks kalimat dalam caption Berikut adalah pemaparan terhadap analisis onomatope tersebut.

\subsection{Bentuk, Fungsi dan Makna Onomatope berakhiran $\sim \supset(t t)$}

1)サクッ (sakutt)

Dalam akun instagram bernama @mognavi.jp ditemukan dua buah data onomatope sakutt.

$\begin{array}{llc}\text { マカロン } & \text { の } & \text { 表面 } \\ \text { Makaron } & \text { no } & \text { hyoumen } \\ \text { makaron } & \text { GEN } & \text { permukaan } \\ \text { は } & \text { サクッ } & \text { と } \\ \text { wa sakutt } & \text { to } \\ \text { TOP } & \text { renyah } & \text { P-KOM } \\ \text { している } & \end{array}$

shiteiru

Melakukan

'permukaan makaron yang terasa renyah'

(31/08/18 diakses dari instagram)

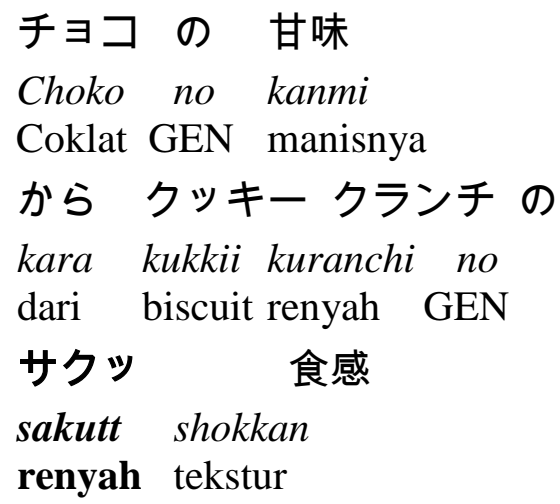

'Tekstur renyah dari biscuit dan manisnya dari coklat'

(04/08/18 diakses dari instagram)

Onomatope sakutt merupakan bentuk onomatope dengan akhiran $\sim \supset(t t)$ yang merupakan onomatope jenis gitaigo atau menunjukkan keadaan dari benda mati. Pada data (1) onomatope sakutt memiliki fungsi gramatikal sebagai adverbial yaitu sebagai penunjuk tekstur renyah permukaan makaron sedangkan dalam data (2) onomatope sakutt berfungsi sebagai pewatas dalam sebuah frasa nomina yang menjelaskan nomina shokkan.

Onomatope sakutt dalam kedua data tidak mengalami perubahan makna gramatikal maupun makna kontekstual. Hal tersebut dapat dibuktikan karena makna kontekstual onomatope sakutt dalam data (1) yang berupa kalimat 'permukaan makaron yang terasa renyah ketika digigit' dan dalam data (2) yang berupa kalimat 'tekstur yang renyah dan manisnya kue dari coklat' sudah sesuai dengan 'menunjukkan suara saat memotong sayuran dan sejenisnya' yang 
dimaksud dalam makna leksikal dari onomatope sakutt.

2) じわつ(jiwatt)

Pada akun instagram bernama @mognavi.jp ditemukan satu buah data onomatope jiwatt.

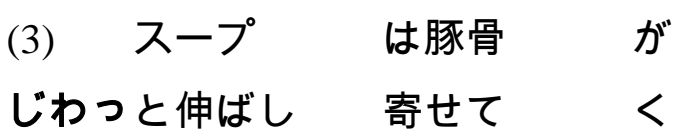
る。

'lemak babi menyebar dalam kuah sup’

(19/01/19 diakses dari instagram)

Onomatope jiwatt sendiri merupakan bentuk onomatope dengan akhiran $\sim \supset$ $(t t)$. Dan merupakan onomatope jenis gitaigo atau menunjukkan keadaan dari benda mati. Pada data (3) onomatope jiwatt memiliki fungsi gramatikal sebagai adverbial karena sebagai pembantu kata kerja nobasu yang mengikuti onomatope yang sudah menerangkan lemak babi yang menyebar dalam kuah.

Onomatope jiwatt, mengalami pergeseran makna gramatikal dan makna kontekstual. Hal tersebut dapat dibuktikan karena adanya verba 'nobasu' setelah onomatope jiwatt yang mengubah makna jiwatt menjadi 'perlahan menyebar' makna kontekstual onomatope jiwatt dalam kalimat 'lemak babi menyebar dalam kuah ramen' dalam unggahan foto oleh food blogger bernama@_pi_no_co__sudah sesuai dengan 'menunjukkan keadaan sebuah cairan yang datang sedikit demi sedikit' yang dimaksud dalam makna leksikal dari onomatope jiwatt.

\section{3） コリッ(koritt)}

Pada akun instagram bernama @mognavi.jp ditemukan dua buah data onomatope koritt.
ココアパウダーのかかった 周りの チ $ヨ コ$ はビターと コリッ とした食感。

'Ketika menggigit coklat yang ditaburi bubuk coklat ini, teksturnya terasa kriuk'

(31/08/18 diakses dari instagram)

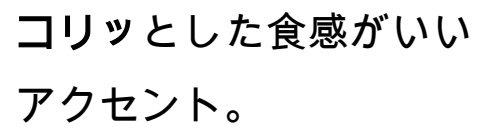

'suara kriuk yang bagus dari tekstur renyah

(01/06/18 diakses dari instagram)

Onomatope koritt sendiri merupakan bentuk onomatope dengan akhiran $\sim \supset$ $(t t)$. Dan merupakan onomatope jenis giongo atau menunjukkan bunyi dari suatu benda atau aktifitas. Pada data (4) maupun data (5) onomatope koritt samasama memiliki fungsi gramatikal sebagai adverbial dalam klausa relatif yaitu samasama menerangkan kata benda yaitu shokkan 'tekstur'.

Onomatope koritt pada data (4) dan data (5) mengalami perubahan padanan makna menjadi 'kriuk'. 'Kriuk' adalah jenis onomatope dalam bahasa Indonesia. Makna onomatope 'kriuk' dengan koritt adalah sama-sama menunjukkan sura dari makanan yang digigit dalam satu waktu atau satu gigitan.

\subsection{Bentuk, Fungsi dan Makna Onomatope A つ B り}

1) こってり(kotteri)

Pada akun instagram bernama @ggg._insta, ditemukan satu buah data onomatope kotteri.

$\begin{array}{lll}\text { マイルド } & \text { な } & \text { こってり } \\ \text { mairudo } & \text { na } & \text { kotteri }\end{array}$




\begin{tabular}{|c|c|c|}
\hline lembut & $\operatorname{adj}$ & kaya rasa \\
\hline した & マヨ & 日ネーズ \\
\hline $\begin{array}{l}\text { shita } \\
\text { melakukan-LA }\end{array}$ & $\begin{array}{r}\text { mayo } \\
\mathrm{M} \text { mayc }\end{array}$ & $\begin{array}{l}\text { oneezu } \\
\text { yonnaise }\end{array}$ \\
\hline みずみずしさ & & を \\
\hline $\begin{array}{l}\text { Mizumizushisa } \\
\text { kesegaran }\end{array}$ & & $\begin{array}{l}\text { wo } \\
\mathrm{ak}\end{array}$ \\
\hline 感じる & & シャキッ \\
\hline と & & \\
\hline $\begin{array}{l}\text { kanjiru } \\
\text { merasakan } \\
\text { P.KOM }\end{array}$ & $\begin{array}{l}\text { shaki } \\
\text { renyah }\end{array}$ & to \\
\hline した & レタス。 & \\
\hline $\begin{array}{l}\text { Shita } \\
\text { Melakukan }\end{array}$ & $\begin{array}{l}\text { retasu } \\
\text { Selada }\end{array}$ & \\
\hline
\end{tabular}

'Rasa mayonnaise yang kaya rasa dan lembut, juga selada yang segar dan renyah'

(11/03/18 diakses dari instagram)

Onomatope kotteri adalah bentuk onomatope dengan bentuk A つ B り. Dan merupakan onomatope jenis gitaigo atau menunjukkan keadaan dari benda mati. Onomatope kotteri pada data (6) memiliki fungsi gramatikal sebagai adverbial dalam klausa relatif yaitu sebagai kata keterangan untuk kata benda mayoneezu.

Onomatope kotteri, mengalami perubahan dalam makna gramatikal maupun makna kontekstual. Hal tersebut dapat dilihat pada makna kontekstual 'menonjol/kuat, sesuatu dalam jumlah yang berlebihan' menjadi 'kaya rasa' setelah mendapat verba shita dan berada dalam konteks menunjukkan rasa dari saus mayonnaise.

\section{2) すっきり(sukkiri)}

Pada akun instagram bernama @__pi_no_co__, ditemukan dua buah data onomatope sukkiri.
すっきりとした ミントと チョコレートのまるやかな 甘さ。

'Rasa yang segar dari mint dan rasa manis coklat yang ringan'

(31/08/18 diakses dari instagram)

$$
\text { 濃厚な味わいの中に す }
$$

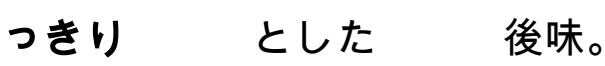

'Rasa yang kuat di dalam dan rasa yang segar di akhir'

(17/11/18 diakses dari instagram)

Onomatope sukkiri sendiri merupakan bentuk onomatope dengan bentuk A つ B り. Dan merupakan onomatope jenis gitaigo atau menunjukkan keadaan dari benda mati. Pada data (7) dan data (8) onomatope sukkiri sama-sama memiliki fungsi gramatikal sebagai adverbial dalam klausa relatif yaitu sebagai kalimat yang menerangkan kata benda, kata benda yang dimaksud yaitu minto pada data (7) dan atoaji pada data (8).

Onomatope sukkiri, tidak mengalami perubahan pada kedua data baik dalam makna gramatikal maupun makna kontekstual. Hal tersebut dapat dibuktikan karena makna kontekstual onomatope sukkiri dalam kalimat 'rasa segar dari rasa mint' pada data (7) dan 'rasa yang kuat di dalamnya dan rasa yang segar di akhir' pada data (8).

\section{3) しつとり(shittori)}

Pada akun instagram bernama @mognavy.jp, ditemukan dua buah data onomatope shikkari. 
（9） 中味が たつぷりつまつ

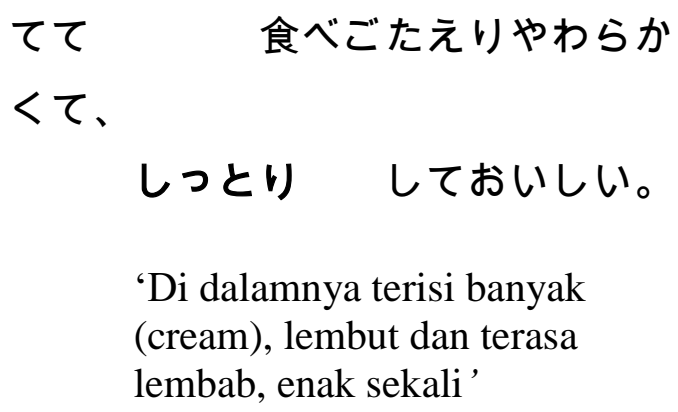

'Di dalamnya terisi banyak (cream), lembut dan terasa lembab, enak sekali'

(10/08/18 diakses dari instagram)

しっとり した薄めの最中

に

$$
\text { バニラ アイス が }
$$

挟まっておる。

'Terisi es krim vanilla yang lembut di tengahnya'

(16/12/18 diakses dari instagram)

Onomatope shittori sendiri merupakan bentuk onomatope dengan bentuk A つ B り. Dan merupakan onomatope jenis gitaigo atau menunjukkan keadaan dari benda mati. Pada data data (9) memiliki fungsi gramatikal sebagai pewatas modifier yaitu memberikan keterangan tambahan untuk kalimat oishii. Sedangkan (10) onomatope shittori sama-sama memiliki fungsi gramatikal sebagai adverbial dalam klausa relatif yang menerangkan kata benda banira aisu 'es krim vanilla'.

Onomatope shittori pada kedua data mengalami perubahan baik dalam makna gramatikal maupun makna kontekstual. Hal tersebut dapat dibuktikan karena makna kontekstual onomatope shittori dalam data (9) dan (10) mengalami pergeseran makna menjadi 'lembut' tidak sesuai dengan makna leksikal onomatope shittori yaitu 'kelembaban yang ringan pada seluruh permukaan benda'.

\subsection{Bentuk, Fungsi dan Makna Onomatope akhiran り(-ri)}

1) とろり(torori)

Pada akun instagram bernama @mognavy.jp, ditemukan dua buah data onomatope torori.

$$
\begin{aligned}
& \text { いちご チョコ クリ } \\
& \text { ーム }
\end{aligned}
$$

Ichigo choko kuriimu Stroberi coklat krim

とろり と

した、

torori to shita meleleh $P-K O M$ melakukan 甘酸っぱい いちご の amasuppai ichigo no asam-manis stroberi GEN クリーム

kuriimu

krim

'krim coklat stroberi yang terasa meleleh, rasa krim stroberinya asam manis.'

(04/06/18 diakses dari instagram)

\begin{tabular}{lll} 
絶妙 & な & \multicolumn{2}{c}{ バランス } \\
zetsumyou & $n a$ & baransu \\
seimbang & adj & seimbang \\
の & とろり & と
\end{tabular}

no torori to

GEN meleleh P-KOM

柔らかい 抹茶 ホイップ

Yawarakaii maccha hoippu lembut teh hijau krim kocok

クリーム が たっぷり

kuriimu ga tappuri

Krim NOM penuh 


\section{詰まってる。 \\ tsumatteru \\ tersumbat}

'Krim maccha yang lembut terisi penuh menjadi perpaduan yang indah' (17/03/18 diakses dari instagram)

Onomatope torori merupakan bentuk onomatope dengan bentuk A つ B り. Onomatope jenis gitaigo atau menunjukkan keadaan dari benda mati. Pada data (11) dan data (12) onomatope torori mempunyai makna gramatikal sebagai adverbial dalam klausa relatif yaitu menerangkan kata benda amasuppai ichigo no kuriimu 'krim stroberi asam-manis' pada data (11) dan kata benda maccha hoippu kuriimu 'krim kocok rasa the hijau' pada data (12).

Onomatope torori, tidak mengalami perubahan baik dalam makna gramatikal maupun makna kontekstual. Hal tersebut dapat dibuktikan karena makna kontekstual onomatope torori dalam kalimat 'krim coklat stroberi yang terasa meleleh, rasa krim stroberinya asam manis' dan kalimat 'Krim maccha yang lembut terisi penuh meleleh dengan perpaduan yang indah'.

\subsection{Bentuk, Fungsi dan Makna Onomatope yang terbentuk dari pengulangan 反復形 (hanpukukei)}

1) ふわふわ (Fuwa-fuwa)

Pada akun instagram bernama @ggg._insta, ditemukan dua buah data onomatope fuwa-fuwa.

$$
\begin{aligned}
& \text { ボリュームたつぷりかき氷！ } \\
& \text { Boryumu tappuri kakigoori } \\
& \text { volume penuh es serut } \\
& \text { その上に は、 ふわふわ } \\
& \text { sonoueni wa fuwa-fuwa } \\
& \text { diatas TOP ringan }
\end{aligned}
$$

$\begin{array}{lll}\text { 甘い } & \text { 練乳 } & \text { エスプーマ } \\ \text { amai } & \text { ren'nyuu } & \text { esupuma } \\ \text { manis } & \text { susu kental } & \text { nama krim }\end{array}$

$\begin{array}{lll}\text { クリーム } & \text { と } & \text { 苺 } \\ \text { kuriimu } & \text { to } & \text { Ichigo } \\ \text { krim } & \text { dan } & \text { stroberi } \\ \text { が } & \text { 三つ。 } & \\ \text { ga hitotsu } & \\ \text { NOM } & \text { tiga buah } & \end{array}$

'Es serut yang terisi penuh! Di atasnya ada tiga buah stroberi dan susu kental manis yang terasa lembut.' (17/08/18 diakses dari instagram)

(14) ふわふわ の スフレ Fuwa-fuwa no sufure Lembut GEN soufflé

$\begin{array}{ll}\text { の 下 } & \text { に さっぱり } \\ \text { no shita } & \text { ni sappari } \\ \text { GEN } & \text { bawah LOK Segar }\end{array}$

目の プリン。

me no purin

mata GEN pudding

'Puding yang menyegarkan mata berada di bawah kue soufflé yang lembut'

(15/09/18 diakses dari instagram)

Onomatope fuwa-fuwa merupakan bentuk onomatope dengan bentuk pengulangan 反復形 (hanpukukei) yang merupakan onomatope jenis gitaigo atau menunjukkan keadaan dari benda mati. Pada data (13) dan data (14) onomatope fuwa-fuwa memiliki fungsi gramatikal sebagai pewatas nomina dalam sebuah frasa nomina yang menjelaskan nomina amai rепуии 'susu kental manis' pada data (13) dan nomina sufure 'souffle' pada data (14). 
Onomatope fuwa-fuwa, tidak mengalami perubahan dalam data (13) dan data (14) baik dalam makna gramatikal maupun makna kontekstual. Hal tersebut dapat dibuktikan karena makna kontekstual onomatope fuwa-fuwa dalam kalimat 'Di atasnya ada tiga buah stroberi dan susu kental manis yang terasa lembut' dan 'Puding yang menyegarkan mata berada di bawah kue soufflé yang lembut'

\section{2) ぱりぱり(pari-pari)}

Pada akun instagram bernama @__pi_no_co__ditemukan dua buah data onomatope pari-pari.

$$
\text { ほんのりミント }
$$

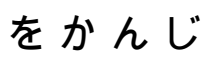

'Teksturnya sempurnah ya! sembari merasakan rasa mint yang tipis juga terdapat banyak coklat chip yang terasa garing'

(31/08/18 diakses dari instagram)

外側は やわらかく、内

側

$$
\text { はぱりぱりの } 2 \text { 種類の }
$$

$$
\text { チョコレート。 }
$$

'coklat dengan dua macam tekstur yaitu garing dibagian dalam dan lembut di bagian luarnya'

\section{(14/12/18 diakses dari instagram)}

Onomatope pari-pari adalah bentuk onomatope dengan bentuk pengulangan 反復形 (hanpukukei). Dan merupakan onomatope jenis gitaigo atau menunjukkan keadaan dari benda mati.
Pada data (15) dan data (16) onomatope pari-pari memiliki fungsi gramatikal pewatas nomina dalam sebuah frasa nomina yang menjelaskan nomina chokkochippu 'biskuit coklat' pada data (15) dan nomina ni-shurui no chokoretto 'dua jenis coklat' pada data (16).

Onomatope pari-pari pada kedua data tidak mengalami perubahan baik dalam makna gramatikal maupun makna kontekstual. Hal tersebut dapat dilihat dari makna kontekstual onomatope paripari dalam kalimat 'Teksturnya sempurnah ya! sembari merasakan rasa mint yang tipis juga terdapat banyak coklat chip yang terasa garing' dan kalimat 'coklat dengan dua macam tekstur yaitu renyah di bagian dalam dan lembut di bagian luarnya' sudah sesuai dengan 'menerangkan suara kunyahan dan benda kering yang dibakar' yang dimaksud dalam makna leksikal dari onomatope pari-pari.

\section{Simpulan}

Dari keseluruhan data yang telah dikumpulkan dari empat buah akun instagram food blogger Jepang tersebut dapat disimpulkan adalah :

Dari seluruh bentuk onomatope tidak semua onomatope memiliki fungsi yang sama. Masing-masing onomatope memiliki fungsi yang berbeda antara lain ada yang berfungsi sebagai adverbial, pewatas dalam sebuah frasa nomina, pewatas modifier, adverbial dalam klausa relatif, pewatas dalam frasa verba, pewatas modifier. adverbial dalam klausa relatif, pewatas dalam sebuah frasa nomina. bentuk onomatope mempengaruhi onomatope yang digunakan dalam menunjukan tekstur makanan dan rasa makanan. Food blogger cenderung menggunakan onomatope dengan akiran $\sim \supset(t t)$ dan onomatope dengan bentuk A つ B り untuk mendeskripsikan tekstur makanan 
sedangkan onomatope dengan akhiran り(-ri) dan Onomatope yang terbentuk dari pengulangan 反復形 (hanpukukei) merupakan onomatope yang digunakan oleh food blogger untuk mendeskripsikan rasa dari makanan tersebut. Makna yang paling banyak muncul yaitu kemunculan makna leksikal sebanyak 7 kali, makna gramatikal sebanyak 5 kali yang dipengaruhi oleh proses gramatikal, makna kontekstual sebanyak 5 kali

\section{Daftar Pustaka}

Chaer, Abdul.2009. Pengantar Semantik Bahasa Indonesia .Jakarta: Rineka Cipta.

Fukuda, Hiroko. 2003. Jazz Up Your Japanese with Onomatopoeia : For All Levels. Japan : Kondansha

Masahiro, Ono.2007. Onomatope ga aru kara Nihongo wa Tanoshii. Japan: Heibonsha.

Surdayanto. 1993. Metode dan Aneka Teknik Analisis Bahasa. Yogyakarta: Duta Wacana Utama Press.

Tamori, Ikuhiro. Lawrence Schourup. 1998. Onomatope: Keitai to Imi. Japan: Kuroshio Shupan.chiro.

Tamori, Ikuhiro. 2002. Onomatope Gion - Gitaigo Wo Tanoshimu. Tokyo: Iwanami.

Toshiko, Atoda Dan Kazuko, Hoshino. 1995. Giongo Gitaigo Tsukaikata Jiten. Tokyo: Shingo. 